\title{
Production and Economic Efficiencies as Influenced by Mustard Genotypes in Paddy Fallows of Tungabhadra Command Area of Karnataka
}

\author{
M. A. Basavanneppa ${ }^{1}$ and B. Arun Kumar $^{2}$ \\ ${ }^{1}$ Agriculture Research Station, Siruguppa, India \\ ${ }^{2}$ Department of Genetics and Plant Breeding, Collage of Agriculture, \\ Bheemarayanagudi, India \\ *Corresponding author
}

\section{A B S T R A C T}

\begin{tabular}{|l|}
\hline Ke y w o r d s \\
Genotypes, Seed \\
and Stalk yields, \\
Gross return, Net \\
return, Economic \\
efficiency.
\end{tabular}

A field trail was carried out at Agricultural Research Station, Siruguppa, Karnataka during summer 20162017 to study the production and economic efficiencies as influenced by mustard genotypes in paddy fallows of Tungabhadra Command Area of Karnataka. The experiment conducted on deep black soil with available nitrogen, $\mathrm{P}_{2} \mathrm{O}_{5}$ and $\mathrm{K}_{2} \mathrm{O}$ of $190.2,18.6$ and $325.4 \mathrm{~kg} / \mathrm{ha}$, respectively. The experiment consists of ten genotypes viz., $\mathrm{V}_{1}$ : Pusa Mustard 25, $\mathrm{V}_{2}$ : Pusa Mustard 26, $\mathrm{V}_{3}$ : Pusa Mustard 27, $\mathrm{V}_{4}$ : Pusa Mustard 28, $\mathrm{V}_{5}$ : Pusa Mustard 29, $\mathrm{V}_{6}$ : Pusa Jagnath, $\mathrm{V}_{7}$ : Pusa Mehak, $\mathrm{V}_{8}$ : Pusa Tarak, $\mathrm{V}_{9}$ : Pusa Agrani and $\mathrm{V}_{10}$ : NRCHB 101, these genotypes were laid out in a complete randomized block design with three replications. The seeds of these genotypes were sown manually at a spacing of $60 \times 10 \mathrm{~cm}$ immediately after the harvest of kharif paddy crop with minimum land preparation. The common fertilizer dose of 90:60:30 kg NPK/ha was applied in the form of urea, diammonium phosphate (DAP) and muriate of potash (MOP). All other recommended agronomic practices were uniformly followed as per the university's manual of Package of Practices. The results reveal that, Pusa Mustard 25 recorded significantly superior seed yield $(872 \mathrm{~kg} / \mathrm{ha})$ and stalk yield (1363 kg/ha) over other genotypes with an yield advantage ranged from 7.11 to $58.9 \%$ over Pusa Mustard 26 and Pusa Agrani $(359 \mathrm{~kg} / \mathrm{ha})$, respectively. However, it was at par with $\mathrm{V}_{1}$ : Pusa Mustard $26(810 \mathrm{~kg} / \mathrm{ha})$. Similarly maximum gross return (Rs. 40283/ha), net return (Rs. 28850/ha), BC ratio (3.52), Production efficiency $(9.38 \mathrm{~kg} / \mathrm{ha} / \mathrm{day})$ and economic efficiency $(310.21$ Rs./ha/day) were recorded in Pusa Mustard 25 compared to other genotypes and it was at par with Pusa Mustard 26. So, it can be conclude that Pusa Mustard 25 and Pusa Mustard 26 were found to be most suitable for paddy fallows in Tungabhadra command area.

\section{Introduction}

India occupies a major share in world oil seed production and it is third largest producer of Rapeseed after China and Canada with contribution of $28.3 \%$ in world acreage and $19.8 \%$ in production. It is cultivating on an area of $5.96 \mathrm{~m}$ ha with production of $8.32 \mathrm{~m} \mathrm{t}$ and productivity of $1397 \mathrm{Kg} / \mathrm{ha}$ (Anon., 2018). The country has been facing the problem of shortage of oils coupled with continuous increase in their prices. Among the mustard growing states, Rajasthan is top Rapeseed and Mustard producing state which accounts to an extent of $48.12 \%$ followed by Madhya Pradesh and Haryana.

Indian mustard (Brassica juncea (L.) Czernj. \& Cosson) is predominantly cultivated in Rajasthan, UP, Haryana, Madhya Pradesh, and Gujarat. It is also grown under some nontraditional areas of South India including 
Karnataka, Tamil Nadu, and Andhra Pradesh. The crop can be grown well under both irrigated and rainfed ecosystem (Kapila et al., 2012). As we observe that there is enormous variability in the climatic and edaphic conditions in the mustard growing areas of India; the selection of appropriate cultivars is prime factor that would ameliorate in enhancing the productivity. Introduction of relatively short duration cultivar found favor with the environment where effective growing seasonal length is short (Kapila et al., 2012).

Tungabhadra command area is one of the most potential irrigated areas in Karnataka where in paddy - paddy is the predominant cropping system in the past years and known as rice bowl of Karnataka, But, in recent years due to vagaries of monsoon in the catchment area coupled with non availability of canal water to grow the second crop of paddy, which in turn prone to searching of an alternate crop suitable for effective utilization of the residual moisture planned to study the production and economic efficiencies as influenced by mustard genotypes in paddy fallows of Tungabhadra Command Area of Karnataka.

\section{Materials and Methods}

A field trail was carried out at Agricultural Research Station, Siruguppa, Karnataka during summer 2016-2017 to study the production and economic efficiencies as influenced by mustard genotypes in paddy fallows under Tungabhadra Command Area of Karnataka. The experiment conducted on deep black soil with available nitrogen, $\mathrm{P}_{2} \mathrm{O}_{5}$ and $\mathrm{K}_{2} \mathrm{O}$ of $190.2,18.6$ and $325.4 \mathrm{~kg} / \mathrm{ha}$, respectively. The experiment consists of ten genotypes viz., $\mathrm{V}_{1}$ : Pusa Mustard 25, $\mathrm{V}_{2}$ : Pusa Mustard 26, $\mathrm{V}_{3}$ : Pusa Mustard 27, $\mathrm{V}_{4}$ : Pusa Mustard 28, $\mathrm{V}_{5}$ : Pusa Mustard 29, $\mathrm{V}_{6}$ : Pusa Jagnath, $\mathrm{V}_{7}$ : Pusa Mehak, $\mathrm{V}_{8}$ : Pusa Tarak, $\mathrm{V}_{9}$ : Pusa Agrani and $\mathrm{V}_{10}$ : NRCHB 101, these genotypes were laid out in a complete randomized block design with three replications. The seeds were sown manually in line at a spacing of $60 \times 10 \mathrm{~cm}$ immediately after the harvest of kharif paddy crop with minimum land preparation. The crop was fertilized at the rate of $90: 60: 30 \mathrm{~kg}$ NPK/ha was applied in the form of urea, diammonium phosphate (DAP) and muriate of potash (MOP). Half of the nitrogen and full doses of $\mathrm{P}$ and $\mathrm{K}$ were applied at the time of sowing and remaining half of $\mathrm{N}$ was top dressed at 30 days after sowing. All other recommended agronomic practices were uniformly followed as per the university's manual of Package of Practices. The data on growth and yield parameters were recorded from 5 randomly selected plants in each genotype plot measuring $5.4 \mathrm{~m}^{2}$ area. Seed yield $(\mathrm{kg} / \mathrm{ha})$ was calculated from net plot area. The cost of cultivation and relative economics of each genotype was calculated on the basis of prevailing market price of the inputs and the produce. Fisher method of analysis of variance was applied for analysis and interpretation of this data as given by Panse and Sukhatme (1967). To work out production efficiency and monetary efficiency following formulae were used;

$$
\begin{aligned}
& \text { Production efficiency (kg/ha/day) }=\frac{\text { Grain Yield (kg/ha) }}{- \text { Crop Duration (days) }^{-0}} \\
& \text { Production efficiency (Rs./ha/day) }=\frac{\text { Net Returns (Rs./ha) }}{\text { Crop Duration (days) }}
\end{aligned}
$$

\section{Results and Discussion}

\section{Growth, yield and yield parameters}

Seed yield of mustard genotypes were significantly differed under field investigation. The highest seed yield (872 $\mathrm{kg} / \mathrm{ha}$ ) and stalk yield (1363 kg/ha) were registered by Pusa Mustad-25, which was 
significantly superior to other genotypes and statistically comparable to Pusa Mustard 26 with $810 \mathrm{~kg}$ seed yield and stalk yield 1267 kg per hectare (Table 1). The similar results are also reported by Mostofa (2016). In the present study, production of higher yield by Pusa Mustard 25 and Pusa Mustard 26 might be due to the contribution of cumulative favorable effects of the crop characteristics viz., days to $50 \%$ flowering (39), days to maturity (93 and 92, respectively) number of branches per plant (11.13 and 10.33, respectively), siliquae per plant (97.87 and 86.17, respectively) and 1000 seeds weight (3.60 and 2.97, respectively) and plant height $(101.3 \mathrm{~cm}$ and $101.0 \mathrm{~cm}$, respectively). It appears that, seed yield was significantly and positively correlated with number of siliquael plant, 1000 seed weight, straw yield, plant height, biological yield and harvest index, which imply that seed yield, would increase with the increase of these yield attributes(Ana et al., 2008 and Zehra et al., 2009). In the present study, higher production efficiency was also registered by Pusa Mustard 25 (9.38 $\mathrm{kg} / \mathrm{ha} /$ day) than rest of the genotypes (Table 2) and it was at par with Pusa Mustard 26 $(8.81 \mathrm{~kg} / \mathrm{ha} /$ day $)$. These results are in line with finding of Meena et al., (2013).

Significantly lower seed yield (359 kg/ha) and stalk yield (562 kg/ha) was observed by Pusa Agrani and it was mainly attributed to low growth parameters like number of branches per plant, siliquae per plant and 1000 seeds weight. Whereas, in another study conducted at Bapatla by Rajyalakshmi et al., (2019) reported that PM-28 variety performed better with superior in growth parameters and yield advantage in rice fallows compared to Pusa bold. Keivanrad and Zandi (2014) observed that increase in seed yield has contributed more oil yield. Sana et al., (2003) reported that, higher number of branches/plant is the result of genetic makeup of the crop and environmental conditions which play a remarkable role towards the final seed yield of the crop.

Table.1 Plant height, yield and yield parameters of mustard genotypes under irrigated condition

\begin{tabular}{|c|c|c|c|c|c|c|c|c|}
\hline Genotypes & $\begin{array}{c}\text { Day to } \\
50 \% \\
\text { flowering }\end{array}$ & $\begin{array}{c}\text { Day to } \\
\text { Physio } \\
\text { logical } \\
\text { maturity }\end{array}$ & $\begin{array}{c}\text { Plant } \\
\text { height } \\
(\mathrm{cm})\end{array}$ & $\begin{array}{c}\text { Seed } \\
\text { yield } \\
(\mathrm{kg} / \mathrm{ha})\end{array}$ & $\begin{array}{c}\text { Stalk } \\
\text { yield } \\
(\mathrm{kg} / \mathrm{ha})\end{array}$ & $\begin{array}{c}\text { No. of } \\
\text { branches/ } \\
\text { pl }\end{array}$ & $\begin{array}{c}\text { No. of } \\
\text { Siliques } \\
\text { /pl }\end{array}$ & $\begin{array}{l}1000 \\
\text { seed } \\
w t(g)\end{array}$ \\
\hline $\mathrm{V}_{1}:$ Pusa Mustard 25 & 39 & 93 & 101.3 & 872 & 1363 & 11.13 & 97.87 & 3.60 \\
\hline $\mathrm{V}_{2}:$ Pusa Mustard 26 & 39 & 92 & 101.0 & 810 & 1267 & 10.33 & 86.17 & 2.97 \\
\hline V $_{3}:$ Pusa Mustard 27 & 41 & 95 & 75.9 & 613 & 955 & 9.57 & 76.40 & 2.51 \\
\hline$V_{4}:$ Pusa Mustard 28 & 42 & 97 & 74.8 & 438 & 686 & 9.50 & 81.90 & 3.10 \\
\hline V $_{5}:$ Pusa Mustard 29 & 40 & 95 & 85.3 & 510 & 798 & 9.47 & 80.90 & 3.26 \\
\hline$V_{6}:$ Pusa Jagnath & 41 & 96 & 83.1 & 471 & 736 & 8.33 & 69.97 & 3.17 \\
\hline$V_{7}:$ Pusa Mehak & 38 & 92 & 75.7 & 537 & 839 & 8.70 & 77.53 & 3.17 \\
\hline V8: Pusa Tarak & 42 & 96 & 84.3 & 405 & 634 & 8.43 & 77.13 & 2.76 \\
\hline V9: Pusa Agrani & 39 & 95 & 81.4 & 359 & 562 & 9.07 & 86.50 & 3.17 \\
\hline $\mathrm{V}_{10}:$ NRCHB 101 & 40 & 95 & 86.5 & 737 & 1151 & 10.40 & 93.27 & 3.47 \\
\hline SEm+/- & & & 0.92 & 27 & 42 & 0.33 & 1.50 & 0.07 \\
\hline CD@5\% & & & 2.74 & 79 & 127 & 0.97 & 4.45 & 0.22 \\
\hline
\end{tabular}


Table.2 Monetary returns of mustard as influenced by genotypes under irrigated condition

\begin{tabular}{|l|c|c|c|c|c|c|}
\hline Genotypes & $\begin{array}{c}\text { Gross } \\
\text { returns } \\
\text { (Rs/ha) }\end{array}$ & $\begin{array}{c}\text { COC } \\
\text { (Rs. } \\
\text { /ha) }\end{array}$ & $\begin{array}{c}\text { Net returns } \\
\text { (Rs/ha) }\end{array}$ & BC ratio & $\begin{array}{c}\text { Production } \\
\text { Efficiency } \\
\text { (kg/ha/day) }\end{array}$ & $\begin{array}{c}\text { Economic } \\
\text { Efficiency } \\
\text { (Rs/ha/day) }\end{array}$ \\
\hline $\mathbf{V}_{\mathbf{1}}$ : Pusa Mustard 25 & 40283 & 11433 & 28850 & 3.52 & 9.38 & 310.21 \\
\hline $\mathbf{V}_{\mathbf{2}}$ : Pusa Mustard 26 & 37411 & 11433 & 25978 & 3.27 & 8.81 & 282.36 \\
\hline $\mathbf{V}_{\mathbf{3}}$ Pusa Mustard 27 & 28281 & 11433 & 16848 & 2.47 & 6.45 & 177.35 \\
\hline $\mathbf{V}_{\mathbf{4}}$ : Pusa Mustard 28 & 20225 & 11433 & 8792 & 1.77 & 4.52 & 90.64 \\
\hline $\mathbf{V}_{\mathbf{5}}$ : Pusa Mustard 29 & 23567 & 11433 & 12134 & 2.06 & 5.37 & 127.73 \\
\hline $\mathbf{V}_{\mathbf{6}}$ : Pusa Jagnath & 21731 & 11433 & 10298 & 1.90 & 4.90 & 107.27 \\
\hline $\mathbf{V}_{\mathbf{7}}$ : Pusa Mehak & 24778 & 11433 & 13345 & 2.17 & 5.83 & 145.05 \\
\hline $\mathbf{V}_{\mathbf{8}}$ : Pusa Tarak & 18702 & 11433 & 7269 & 1.64 & 4.22 & 75.72 \\
\hline $\mathbf{V}_{\mathbf{9}}$ : Pusa Agrani & 16541 & 10950 & 5591 & 1.51 & 3.78 & 58.85 \\
\hline NRCHB 101 & 34007 & 11433 & 22574 & 2.97 & 7.75 & 237.62 \\
\hline SEm+/- & 1225 & & 1225 & 0.106 & 0.278 & 12.85 \\
\hline CD@5\% & 3668 & & 3668 & 0.319 & 0.832 & 38.47 \\
\hline
\end{tabular}

\section{Monetary benefits}

Mustard genotypes showed significant differences in the monetary returns (Table 2). Pusa Mustad-25 recorded significantly higher gross return (Rs. 40283/ha), net return (Rs.28850/ha), Benefit cost ratio (3.52) and economic efficiency (310.21 Rs./ha/day) compared to rest of the genotypes. However it was on par with Pusa Mustard 26 (Rs.37411/ha and Rs.25978/ha, gross and net returns, respectively). This higher gross return and net return was mainly attributed to higher yield in the same genotypes. Pusa Muastard 25 recorded significantly maximum economic efficiency (Rs. 310.21/ha/day) compared to rest of the genotypes. Whereas significantly minimum gross return (Rs. 16541/ha), net return (Rs. 5591/ha), Benefit cost ratio (1.51) and economic efficiency (Rs.58.85/ha/day) was registered with Pusa Agrani. This was mainly due to fewer yields.

Pusa Mustard 25 recorded significantly superior seed yield ( $872 \mathrm{~kg} / \mathrm{ha})$ and stalk yield (1363 kg/ha) with yield advantage ranged from 7.11 to $58.9 \%$ over Pusa Mustard 26 and Pusa Agrani (359 kg/ha), respectively.
Similarly maximum gross return (Rs. 40283/ha), net return (Rs. 28850/ha), BC ratio (3.52), Production efficiency $(9.38 \mathrm{~kg} / \mathrm{ha} /$ day $)$ and economic efficiency (310.21 Rs./ha/day) were maximum in Pusa Mustard 25 compared to other genotypes and it was at par with Pusa Mustard 26. So, it can be conclude that Pusa Mustard 25 and Pusa Mustard 26 genotypes were found to be most suitable for paddy fallows in Tungabhadra command area of Karnataka.

\section{References}

Ana, M. J., M. Radovan, and Anto, M. 2008. Correlation and path analysis of quantitative traits in winter rapeseed (B. napus L.). Agric Conspec Sci. 73(1):13-18.

Annonymous, 2018. Agricultural Statistics at a Glance, Directorate of Economics and Statistics, Department of Agricultural and Cooperation. Ministry of Agriculture, Government of India.

Kapila Shekhawat, S. S., O.P. Rathore, B. K. Premi, Kandpal, and Chauhan, J. S., 2012. Advances in Agronomic 
Management of Indian Mustard (Brassica juncea (L.) Czernj. Cosson): An Overview. International Journal of Agronomy. doi:10.1155/2012/408284

Keivanrad, S., and Zandi, P. 2014. Effect of nitrogen levels on growth, yield and oil quality of Indian mustard grown under different plant densities. Cercetari Agronomice in Moldova. 47(1):81-95.

Meena, D. S., V. R. Meena, and Meena, A. K. 2013. Fertilizer management studies on growth and productivity of hybrid Indian mustard Brassica juncea (L.). Journal of Oilseed Brassica. 1(1):3942.

Mostofa Uddin Helal Md, Nazrul Islam Md, Monjurul Kadir, and Noor Hossain Miah, 2016. Performance of rapeseed and mustard (Brassica sp.) varieties/lines in north-east region (sylhet) of Bangladesh. Adv Plants
Agric Res. 5(1):457-462.

Panse, V. G. and Sukhatme, P. V. 1967. Statistical Methods for Agricultural Workers, ICAR publications, New Delhi.; p 359.

Rajyalakshmi, B., B. Venkateswarlu, P. V. N. Prasad, and. Prasad, P.R.K. 2019. Yield, quality and sulphur uptake of mustard genotypes as influenced by seed rates in rice fallows. International Journal of Chemical Studies. 7(3): 2821-2824

Sana, M., A, Ali, and Malik, M. A. 2003. Comparative yield potential and oil contents of different canola cultivars (Brassica napus L.). Pakistan J Agron. 2(1):1-7.

Zehra, A. and Gulcan, K. 2009. Genetic variability and association studies of some quantitative characters in winter rapeseed (Brassica napus L). African J Biotec. 8(15):3547-3554.

\section{How to cite this article:}

Basavanneppa. M. A. and Arun Kumar. B. 2020. Production and Economic Efficiencies as Influenced by Mustard Genotypes in Paddy Fallows of Tungabhadra Command Area of Karnataka. Int.J.Curr.Microbiol.App.Sci. 9(06): 2376-2380.

doi: https://doi.org/10.20546/ijcmas.2020.906.291 